IJ§ER

ISSN: $2149-5939$
International Journal of Social Sciences and Education Research

Online, http://dergipark.gov.tr/ijsser

Volume: 3(3), 2017

\title{
Examining the effects of green marketing on the purchasing behaviours of consumers in socio-demographic aspects
}

\author{
Adnan Veysel Ertemel ${ }^{1} \quad$ Anıl Türkoğlu²
}

Received Date: $01 / 01 / 2017$

Accepted Date: 12 / 03 / 2017

\begin{abstract}
The rapidly developing globalization has brought along many problems with it. The biggest ones of those problems are the environmental problems that directly affect all humanity. These problems that have a negative effect human health caused the consumers to worry about their futures. With the consumers starting to understand the consequences of the damages they impose on the environmental due to their own actions, changes occurred in their purchasing behaviors and they started to turn to green products. This change in the consumer behavior provided the marketers to make revisions in their general marketing techniques and to bring about the green marketing approach. The marketing of environmental friendly products started to be performed with green marketing techniques thanks to this approach and it was aimed to minimize the environmental damage caused by the consumers and manufacturing companies. In this research, a survey is conducted that measures the influence of green marketing works on the purchasing behaviors. The most significant results to confer from this research are as follows: the green marketing purchasing behavior of female consumers is significantly different than the male consumers. However, there is no relation between the age, educational status, income and professions and their other relevant socio-demographic properties and their green purchasing behaviors. In addition to all this, it has been conferred that the consumers could pay more for the green products.
\end{abstract}

Keywords: Green marketing, consumer purchase behaviour, green marketing mix, green marketing tools

\section{Introduction}

With the process that started with the industrial revolution, changes occurred in basic raw material and resources as in many areas. Chemicals other than coal and iron started to be used, new inventions were on the one hand in favor for humanity but caused an increase in the amount of $\mathrm{Co} 2$ on the other hand due to its unconscious utilization and thus caused many environmental problems. The most important among these environmental problems is global warming. Global warming created significant influences on the seasons and caused changes. These changes brought along many problems like the rings of a chain and started to reach to the level to threaten human health. Significant increases took place in the weather temperatures due to global warming compared to the last 50 years. These increases started to cause the extinction of many beings and some changes in the natural balance. Due to the increasing weather temperature, drought and consequently interruptions in agricultures took place in some regions because of the decrease in water resources and even the drought of some resources.

Many consumers started to comprehend what their manufacturing behaviors and their behaviors toward the nature caused by going through the abovementioned problems. This wake-up call of the consumers and the thought that the normal marketing approach could challenge the nature

\footnotetext{
${ }^{1}$ Asist. Prof. Dr., İstanbul Ticaret University, Business Administration Faculty, Istanbul adnanertemel@gmail.com

${ }^{2}$ MBA, İstanbul Bahçeşehir University, İstanbul turkogluanil@gmail.com
} 
Ertemel, A. V., Türkoğlu, A. (2017). Examining the effects of green marketing on the purchasing behaviours of consumers in socio-demographic aspects International Journal of Social Sciences and Education Research, 3(3), 704-710.

slowly got replaced with a more environmental friendly dimension. The concerns of the consumers regarding the future led them to buy green products. The consumers started to wish to minimize the environmental damage by purchasing green products. The marketers and companies also shared these concerns and went for new marketing approaches. In time, the existing consumer purchasing behaviors changed and many concepts were created such as green product, green price, green promotion, green distribution, and green consumption.

\section{Green marketing}

Term of "green marketing" was firstly discussed in a seminar about "ecological marketing" organized by American Marketing Association (AMA) in 1975. In this seminar impact of marketing on natural environment was analyzed by academics, practitioners, and public policy makers and result of this seminar ecological marketing was defined as: studies regarding negative or favorable impacts on environmental pollution, energy consumption and consumption of other resources as result of marketing (AMA, 1975; May 1991).

In 1990's many marketing research shows that lots of consumers interested about the sustainibility of the environment. Most of the companies responded to this development by revising their advertisement campaigns according to green marketing principles. (Peattie \& Crane, 2005, pp. 360-361). Nowadays in Europe, expanding interest for green marketing is being observed. Green marketing consist of many activities including process modification, product changes and environmentally friendly changes for packaging and also advertisement. Most of the consumer think that green marketing refers to promote or advertised the products with ecological attributes. There are many new terms invented to define green marketing; recycle, ozone friend and eco friend. Green marketing is a developing concept and it can be applied on a broad range of terms, consumer behaviours, industrial outputs and even services (Grundey \& Zaharia, 2008, pp. 130).

Green marketing can be considered as a concept mostly related with the emphasising of the "green side" of the product which makes it differentiated from the traditional marketing. This concept also include the design of the product in a bottom to top approach and make it eligible for "green marketing" for the ones who are labeled as "green consumers" whose first concern about shoping experience is environment.

Growing interest for the green products at all sections of the society have led to a significant increase in number of products labeled as "green" (Jansson, Marell \& Nordlund, 2010, p. 358).

According to Polosky, environmental/green marketing contain all of the activities for satisfy consumer needs and wants, such that the satisfaction of these needs and demands occurs, with giving minumum negative impact on natural environment.

The United Nations Environment Program defines green marketing is involve all communication activites for promote a product, put center its environmental properties or of its social qualities.

While considering the different academical approaches related to "green marketing" it can be filtered as a logic which is consisting of identifying, planning and satisfying of the green consumers in a sustainable and also green way. 
Ertemel, A. V., Türkoğlu, A. (2017). Examining the effects of green marketing on the purchasing behaviours of consumers in socio-demographic aspects International Journal of Social Sciences and Education Research, 3(3), 704-710.

\subsection{Evaluation of green marketing}

During the green marketing's developments it has passed different stages. Every stage has individual characterictics and changing situational and environmental needs.

Green marketing has passed three stage, the first, ecological green marketing which lasted from 1960s into the early 1970s. The second stage, green enviromental marketing, this era began in the late $80 \mathrm{~s}$. The third stage is sustainable green marketing.

First phase was named Ecological green marketing and during this all marketing activities were concerned to help enviroment problems and provide remedies for envirnmental problems.

The second phase was Enviromental green marketing was focused the innovative new product which respect the environment.

Third phase was "sustainable" green marketing. It came in to prominence in the late 1990's early 2000 .

There are some important differences between the environmental movement of the 1970s and the green movement of today. In 1970's environmentalism just focused the environmental problems but 1990's green perception focusing the problems which related with social, economic, technical or legal sytems. The other discrepancy is domain; at the first perception was interet with local problems but latest green perception relevant with global issues.

\subsection{Theoretical structure and hypothesis}

Theoretical structure of this questionnaire was built on review of literature on green marketing and green purchasing behavior. Most of the consumer start to understand the importance of environment therefore they revise their consumer behavior. Marketers also had to revise their strategy thus green marketing was born. Consequently, following hypotheses are developed:

Hypothesis 1: There is a significant relationship between gender of consumers and purchasing behavior on green marketing.

Hypothesis 2: There is a significant relationship between civil status of consumers and purchasing behavior on green marketing.

Hypothesis 3: There is a significant relationship between education levels of consumers and purchasing behavior on green marketing.

Hypothesis 4: There is a significant relationship between age differences of consumers and purchasing behavior on green marketing.

Hypothesis 5: There is a significant relationship between monthly income of consumers and purchasing behavior on green marketing.

Hypothesis 6: There is a significant relationship between professions of consumers and purchasing behavior on green marketing 
Ertemel, A. V., Türkoğlu, A. (2017). Examining the effects of green marketing on the purchasing behaviours of consumers in socio-demographic aspects International Journal of Social Sciences and Education Research, 3(3), 704-710.

\section{Analysis and finding}

\subsection{Descriptive Statistics}

In this study the results show that there is $38 \%$ male and $62 \%$ female participants applied to this study. Regarding the rates of participants, rate of female participants are higher than rate of male participants. $59 \%$ of participants are bachelor and $41 \%$ of participants are married. It is showing that the $\% 51$ of the participants are between 19 and $29,36 \%$ of participants are between $30-39$ ages, $10 \%$ of participants are between $40-49$ ages and $4 \%$ of participants are 50 or above. When we examine education level of the participants, the results show that $3 \%$ of participants graduated from primary school, $10 \%$ graduated from high school, $68 \%$ graduated from college and $19 \%$ has master's education. It is showing that the share of the 19 to 29 age group is the highest. Second biggest share of age distribution is allocated for ages between 30 and 39. There are only 6 people in 50 or above group.

\subsection{Reliability and validation}

In this questionnaire study, Co. Alpha analysis technique is practiced for testing of reliability of 12 statements about socio-demographic characteristics of consumers and consumers purchasing behavior on green marketing. In the result of this analyze; Co. Alpha coefficient is determined as 0,98 . This rate shows that these results are quite confidential. Because of this reason, there is no need to eliminate any question from this questionnaire. After analyzing of reliability, factor analyzing technique is practiced for testing validation of 12 statements scale.

In the result of the factor analysis, only one dimension was determined and it is termed as socio-demographic characteristics of consumers and consumers purchasing behavior on green marketing. KMO sample validation Coefficient rate was determined as 0, 82 in factor analysis. This rate shows that 160 participants are enough to reveal the questionnaire's factor format. Moreover, the results of Bartlet test which testing the factor form's meaningfulness, acquired forms are meaningful. $(\mathrm{p}=0,01, \mathrm{p}<0,05)$

\section{Determination of factors which affect consumer's purchasing behaviors according to marketing activities}

\subsection{Gender}

According to acquired results there are differences between Male and Female participants' purchasing behaviors according to green marketing activities $(t=-3,14, p<0,05)$. Reason of this difference is seen as female participants are interested on green marketing activities more than male participants. Acquired results show that gender is variable factor on purchasing behavior of consumers according to green marketing activities.

\subsection{Civil}

Civil Status and Purchasing behavior of consumers according to green marketing activities.

According to acquired results, it is determined that civil status of the participants has no effect on purchasing behavior of consumers according to green marketing activities. ( $t=1,59, \mathrm{p}>0,05)$. Married and bachelor people's purchasing behaviors on green marketing activities are seen as 
Ertemel, A. V., Türkoğlu, A. (2017). Examining the effects of green marketing on the purchasing behaviours of consumers in socio-demographic aspects International Journal of Social Sciences and Education Research, 3(3), 704-710.

similar levels. Consequently, the results show that civil status of the participants is not variable factor on purchasing behavior of consumers according to green marketing activities.

\subsection{Age}

Age and Purchasing behavior of consumers according to green marketing activities.

According to acquired results, it is determined that age differences of the participants have no effect on purchasing behavior of consumers according to green marketing activities. ( $\mathrm{F}=2,05$, $\mathrm{p}>0$, 05). Rate of participants who are in 19-29, 23-39, 40-49 and more than 50 ages shows similar levels according to purchasing behaviors on green marketing activities. The results show that age differences of the participants are not effective and variable factor on purchasing behavior of consumers according to green marketing activities.

\subsection{Education}

In this study independent Variance analysis test technique (ANOVA) is practiced for investigating the effects on relationship between education levels of participants and consumer's purchasing behaviors. Acquired results are presented in the below chart as a summary.

Education levels and purchasing behavior of consumers according to green marketing activities.

According to acquired results, it is determined that education levels of the participants have no effect on purchasing behavior of consumers according to green marketing activities. $(\mathrm{F}=0,54$, $\mathrm{p}>0,05)$. Primary school education, high school education, college education and master education rates of the participants show similar levels according to purchasing behaviors on green marketing activities in the chart. The results show that education levels of the participants are not effective and variable factor on purchasing behavior of consumers according to green marketing activities.

\subsection{Income}

In this study independent Variance analysis test technique (ANOVA) is practiced for investigating the effects on relationship between income levels of participants and consumer's purchasing behaviors on green marketing activities. Acquired results are presented in the below chart as a summary.

Income and Purchasing behavior of consumers according to green marketing activities.

According to acquired results, it is determined that Income levels of the participants have no effect on purchasing behavior of consumers according to green marketing activities $(\mathrm{F}=1,43$, $\mathrm{p}>0,05)$. Purchasing behaviors on green marketing activities of the participants who earn 1200 TL and below, 1201-2000TL, 2001-3000TL, 3001-4000TL and 4001TL and above are in similar levels in the chart. The results show that monthly income levels of the participants are not effective and variable factor on purchasing behavior of consumers according to green marketing activities.

\subsection{Profession}

In this study, independent Variance analysis test technique (ANOVA) is practiced for inves- 
Ertemel, A. V., Türkoğlu, A. (2017). Examining the effects of green marketing on the purchasing behaviours of consumers in socio-demographic aspects International Journal of Social Sciences and Education Research, 3(3), 704-710.

tigating the effects on relationship between professions of participants and consumer's purchasing behaviors on green marketing activities. Acquired results are presented in the below chart as a summary.

\section{Profession and Purchasing behavior of consumers according to green marketing activities.}

According to acquired results, it is determined that professions of the participants have no effect on purchasing behavior of consumers according to green marketing activities $(\mathrm{F}=0,57$, $\mathrm{p}>0,05)$. Purchasing behaviors of participants who are professionals, proprietors, officers or employees, students, unemployed are seen in similar levels. The results show that profession varieties of the participants are not effective and variable factor on purchasing behavior of consumers according to green marketing activities.

\section{Conclusion}

In this day and age when we are even more exposed to the consequences of environmental problems what with global warming, it is in question that many social, political, health-related and economic disasters may take place should the necessary actions are not taken. Also, it is argued that the starting point in the forming of environmental problems and in the solution of the problems is consumption and not production. At this point, what the consumers consume how much and how along with their behaviors after consumptions became an important issue. In this study, it has been aimed to determine whether there is a relation between the consumers purchasing green products and their demographic properties. As a result of the hypothesis tests, a significant relationship has been found between green purchasing behavior and only gender but not between age, marital status, educational level and monthly income. According to the results of the research, the behaviors of the female consumers of purchasing green products are higher.

In our country, it is considered that women are responsible for the family. Women think that they are responsible for the shopping, for the protection of the health of the family members and providing the development of their children, for contributing to the family budget and all the while for protecting the environment. Thus, the results obtained in this study suggest that women have a greener product consuming behavior than men. Additionally, it has been determined that the persons participating in the survey could pay about $16 \%$ more in order to buy green products. Even though the environmental issues can be perceived as a threat by the marketers, it can also become an opportunity that can be rendered in favor for the marketers. The increasing environmentalist sensitivity among the consumers is reflected on their purchasing decisions and also increases may occur in the purchasing itself. Therefore, a new target market takes place consisting of the consumers opting for green products in their purchases. And the determination of the profile of these consumers will without a doubt have significant contributions in dividing this market into market sections and in developing the marketing factors that meet their needs/demands. It was aimed to try to determine the demographic properties of the consumers purchasing green products. At this point, it is hoped that useful information can be provided by the study in the division of the market into sections. However, in addition the demographic factors to better interpret the green purchasing behaviors, the psychographic properties should also be researched and applied.

\section{References}

Grundey, D., \& Zaharia, R.M. (2008). Sustainable incentives in marketing and strategic greening: the cases 
Ertemel, A. V., Türkoğlu, A. (2017). Examining the effects of green marketing on the purchasing behaviours of consumers in socio-demographic aspects International Journal of Social Sciences and Education Research, 3(3), 704-710.

of Lithuania and Romania. Baltic Journal on Sustainability, 14(2), pp.130-143.

Jansson, J., Marell, A., \& Nordlund, A. (2010). Green consumer behavior: determinants of curtailment and eco-innovation adoption, Journal of Consumer Marketing, pp.358- 370.

Peattie, K., \& Crane, A. (2005). Green marketing: legend, myth, farce or prophesy 8(4). Qualitative Market Research: An International Journal, pp.357-370.

Young, CW, Hwang, K, McDonald, S and Oates, C (2010). Sustainable consumption: green consumer behaviour when purchasing products. Sustainable Development, pp.18-31

Michael Jay Polonsky, “An introduction to green marketing”, Electronic Green Journal (1994), vol. 1,No. 2. http://ogma.newcastle.edu.au:8080/vital/access/manager/Repository/uon:3104 [accessed 12 January 2015]

United Nations Environment Programme, Sustainability Communications: A Toolkit for Marketing and Advertising Courses (Nairobi, 2005). www.unep.fr/shared/publications/pdf/DTIx0886xPA-EducationKitEN.pdf [accessed 12 January 2015]. 